\title{
The Proletarian Literature Movement: Japan's First Encounter with Working-Class Literature
}

Mats Karlsson

Japan of the interwar era is mostly associated, in both national and international memory, with its gradual descent into totalitarianism, or even outright fascism as some scholars would have it. The milestones of this trajectory are well-known: the introduction of the so-called Peace Preservation Law of 1925 , aiming to counter any leftist leaning opposition throughout society; the outbreak of the Manchurian Incident in I93 I; the plunge into total warfare with China in I937; the dissolvement of party parliamentarism in I940; finally culminating in the attack on Pearl Harbor and Japan's entry into World War II in I94I.

Yet it is probably less well-known that the Japan of this era initially experienced social unrest and a major challenge to the hegemony of authoritarian rule, which was implemented by various constellations of "bourgeois" reactionary political parties. The challenge was posed by a vigorous labor and peasant union movement, underpinned by socialist political parties of different gradation and left-leaning intellectual fellow travelers. This broad labor movement had an independent cultural wing - even though the banned underground Japanese Communist Party identified the cultural arena as their sole legal venue to reach out to the public and therefore strove to place it under its control- operating under the common denomination of The Proletarian Cultural Movement [Puroretaria bunka undō], which existed for about

How to cite this book chapter:

Karlsson, M. 2020. The Proletarian Literature Movement: Japan's First Encounter with Working-Class Literature. In: Lennon, J. and Nilsson, M. (eds.) WorkingClass Literature(s): Historical and International Perspectives. Volume 2. Pp. II 5-I37. Stockholm: Stockholm University Press. DOI: https://doi. org/Io.I6993/bbf.e. License: CC-BY 4.0. 
a decade, peaking in the late I920s. The Cultural Movement functioned as an umbrella organization with eleven subgroups operating in various fields, ranging from film and theatre to the education of children and the teaching of Esperanto. Yet, the leadership of the Cultural Movement deemed literature to be the most influential cultural field, upon which they focused their activities. Thus, writers organized under the Japan Proletarian Writers' League [Nihon Puroretaria Sakka Dōmei] were entrusted with spearheading the movement as exemplars for other types of artists and cultural workers to emulate. Except for pure literary pursuits, writers were also tasked with projects like organizing literary circles on the factory floor and in the farming villages across Japan. While many members of the movement participated out of a genuine and self-sacrificing wish to create a more equal society and spread enlightenment to workers and other unprivileged segments, the movement's leadership and labor union activists tended to take a more utilitarian view of the cultural efforts as, first and foremost, a means to propagate their ideology and pave the way for union activism.

Even before literature became politicized in the twenties, there had been socially conscientious novels written in Japan, starting with the "imported" naturalistic school and its portrayal of the lower strata of society at the beginning of the century. The novelist Shimazaki Tōson (1872-1943) is widely credited with ushering in a socio-political perspective with his 1906 novel The Broken Commandment [Hakai], which treats the social issue of the so-called

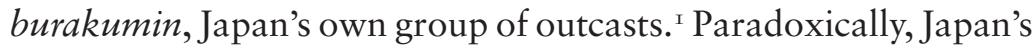
version of naturalism soon became side-tracked into a selfreferential type of supposedly confessional novel (shishōsetsu, or 'I-novel'), based on the logic that if the faithful depiction of reality were to be the objective of literary depiction, then surely there is nothing an author can be more truthful about than himself. ${ }^{2}$ With the spread of leftist ideology throughout the twenties in the wake of the Russian Revolution, discontent with widespread poverty and social inequality increasingly became expressed within a Marxist-Leninist framework. Meanwhile, in the field of literature, the hegemonic I-fictional type of myopic belles-lettres turned unfashionable as writers and intellectuals argued for the 
need of a more socially conscientious mode of expression. What was new in the current literary approach was that emerging writers started to treat inequality and deteriorating working conditions as elements of class struggle. To various degrees, literature thus became dependent on politics. To the already convinced, the increasingly worsening economic conditions in the wake of the Great Depression corroborated Marxian theoretical projections that international capitalism had entered its period of final collapse, characterized by heightened exploitation of the toiling masses at home and imperialism abroad, the two main literary themes of Japanese proletarian fiction. Authorities, for their part, initially tolerated-although unwillingly and just barely-leftist leaning writers and artists to operate. Soon, though, they began harassing and persecuting them more severely until ultimately shutting down the whole Proletarian Cultural Movement initiative towards the middle of the thirties, on the sometimes true pretext that the various cultural groups contained Communist Party cells within them. ${ }^{3}$

\section{Origins of Working-Class Literature in Japan}

But how did it all begin? Let us first return to I923, the year when The Great Kanto Earthquake struck Tokyo leaving approximately I 43,000 people dead in its wake. The following excerpt is drawn from the opening of Literary Reminiscences [Bungakuteki kaisō], written by Hayashi Fusao (1903-1975), one of the instigators and most prominent members of the proletarian literary movement. Hayashi had enrolled at the Tokyo Imperial University in I923, where he soon joined the New Man Society [Shinjinkai], formed by students at the university in $19 \mathrm{I} 8$, originally as a democratic discussion forum. By 1923, though, it had turned into a Marxist study circle, including members of Japanese Communist Party cells. During the summer break of 1923 Hayashi returned to his rural hometown in Kyushu with the aim of involving local youth organizations in the budding nationwide student socialist movement. It is against this background that the following occurs:

It seemed the comrades who had returned to other regions were steadily achieving results. In contrast, I was only doing things like 
forming useless 'cultural circles' comprising returnee students that had no effect whatsoever on workers or the youth in rural communities. While I was agonizing all on my own and feeling frustrated over letting other comrades down, the summer holidays ended. Then came September I, the day of the Great Kanto Earthquake. All page space of the regional newspapers was occupied with preposterous headlines and articles. 'The Imperial Capital reduced to a field of burned-out ruins in an instant.' 'Mount Fuji caves in.' 'A large troop of Koreans lead by Socialists clashes with the military.' 'Street fighting in Kōtō, no prospect of subjugation say the authorities.' 'His Imperial Highness the Crown Prince missing.' What startled me was neither the annihilation of the capital of Japan nor the cave-in of Mount Fuji. It was the street fighting in Tokyo; in other words, the fact that the revolution had occurred. The comrades had taken to arms; built barricades, raised the Red Flag and were fighting the imperialists' army. Surely, it cannot be the Koreans only. All workers and oppressed masses of Tokyo must have joined the revolutionary army. It had probably brushed off the resistance of the military and the police to make an advance on the Imperial Palace. While I had been putting useless effort into a tedious enlightenment movement in a provincial town, the revolution had broken out. Had I only advanced the date for going to Tokyo slightly, I would have been in time. With a time difference of only a day or two I had become a dropout from the revolution, a class traitor. I walked about the hills aimlessly and came out onto the seashore. I pilfered a small fishing boat and rowed out to sea. I wished for a storm to occur and the boat to capsize. Revolution dropouts ought to sink into the sea and die! But no storm occurred and the moon arose in the clear sky. Crestfallen I rowed the boat back to shore. (Hayashi, I955, pp. 6-7)

In his reminiscences, Hayashi uses this anecdote to illustrate how his communism had been built on fanaticism and illusion and that the whole proletarian literary movement initiative itself becomes inexplicable if we bracket this naïve and primitive, as he would later have it, fanaticism for revolution. ${ }^{4}$ For devoted followers, it thus appears that the coming of the revolution was only a question of when, not if. Remember that The Russian Revolution was in fresh memory at the time and the Soviet socialist experiment had just started after their civil war. Needless to say, we are still in an era years before the first authentic reports of facets of Soviet daily life had started to trickle out. Even so, surveying the 
proletarian cultural movement in retrospect, it is difficult to gauge whether genuine faith in the eventual coming of revolution was ever widespread, or whether the optimistic and assertive rhetoric should largely be assigned to the genre of Marxist true-speak.

Besides literature proper, an astonishing amount of discourse was produced and circulated during the hectic years that this literary movement was in operation, ranging from conceptual explications of dialectical materialism, commentary on and translations of the latest Bolshevik party programs, advice on how to initiate literary circles on the factory floor, to manifestos and political propaganda instruments. Throughout, the rhetoric is underpinned by the conviction that the movement is delivering cultural enlightenment to the unprivileged, tapping into a latent "thirst for knowledge" [chishiki-yoku] among the masses, to reference one of the terms circulating in the discourse. If we bracket the call for revolution, the movement can perhaps in this sense be seen as a socio-cultural project meant to raise the level of awareness of workers and peasants much in line with the aims of contemporary social-democratic movements in Europe. Even if they had had the chance to operate freely, it is, however, doubtful that the movement would have been able to radicalize the peasants and workers to the intended extent. In the first national election held under the Universal Manhood Suffrage Law, in early I928, the two main "bourgeois and landlord" parties received around 8.5 million votes and 436 returned candidates, as compared to slightly less than half a million votes and eight returned candidates for the various leftist labor-farmer parties and social democrats, including local "proletarian" parties (Beckman and Okubo, I969, pp. I $5 \mathrm{I}-52$ ).

In general, when envisaging working-class literature, one is prone to think of literature written by and for workers. In Japan, though, it was originally the leftist student movement that provided the hotbed for literary initiatives. Beginning with the abovementioned New Man Society, groups for the study of social science had started popping up at universities and other schools around the country, organized in 1924 under a nationwide student federation [Gakusei shakaikagaku rengōkai]. Around this time the study of "social science" basically meant the study of Marxist theory, which was widely and eagerly undertaken at universities 
and among intellectuals. Marxist theory was also disseminated through venues such as the influential progressive general interest journal Reconstruction [Kaizō], even though the ideology as such carried dangerous "red" overtones to wider society outside of the intelligentsia. Needless to say, Marxism was not the only foreign derived ideology à la mode in the Japan of that time. Kawaguchi Hiroshi (I905-I984), a central figure in the literary movement's leadership, has described how everything in student circles was in a state of flux, yet interconnected:

The trend of the time that was overflowing among the young and energetic rebels was a yearning for radical reform in all fields of art. That trend was by no means only funnelled in a socialist direction. There was the constructivism of Murayama Tomoyoshi, the futurism of Kanbara Tai, the Dadaism of Takahashi Shinkichi [...] The ensigns might have varied between the groups, but generally all of them were ambitious coteries for art reform spurred on by the self-confidence that it is our very course that make up the vanguard. Our inclination was by no means separated from this general current of the times. (Kawaguchi, I97I, p. I 5)

When Kawaguchi enrolled at Tokyo Imperial University in I925, he was first involved in a radical theatre group together with comrades from Japan's contemporary version of high school before the group was won over by New Man Society under the auspices of Hayashi, who had laid eyes on the radical group:

We gradually became enlightened and brainwashed by Hayashi. Through reading books like The ABC of Communism [by Nikolai Bukharin and Evgenii Preobrazhensky] and The Bolshevik Party Programme we were awakened to the truth. It felt like a truly new world suddenly opened itself up in front of our eyes. This was something we could sympathise with from the bottom of our hearts, exactly what we had been yearning for all the time. We realised that it had to be a revolutionary art not only an artistic revolution. Nothing would come from pursuing mere novelty or eccentricity; we had to rethink more fundamentally. For this purpose, it was essential to thoroughly study social science and Marxism, enough of makeshift theatre - this was our conclusion. Upon which all of us entered New Man Society one after the other. (Kawaguchi, I97I, p. I8) 
It emerges from the literature that the labor movement proper looked down on fellow cultural workers for not doing the hard dirty work themselves. In fact, though, without the contributions by young, idealistic and self-sacrificing students, there would neither have been a documentation of the movement by cultural means as we know of it today, nor such a strong ideological and theoretical base for the unfolding political struggle.

\section{In Search of "True" Worker Writers}

From its inception, then, the Proletarian Literature Movement was defined by a high level of dependence on intellectuals and students, and by a dearth of writers with a working-class background. Both lenient leftists, congregating around the journal Literary Front [Bungei sensen], and hard-line doctrinaire Marxists, congregating around their Battle Flag [Senki], put the cultivating and advancing of "true" worker writers as the first item on their agendas. ${ }^{5}$ In a comparative perspective, the issue of what amounts to a "true" worker writer mirrored similar ongoing contemporary concerns surrounding the proper custodians of proletarian literature in the Soviet Union (see Clark 20I7). During this period, Kurahara Korehito (I902-I99I), the chief theoretical architect behind the hard-line wing, chastized its writers for focusing on labor disputes while shunning actual depictions of labor in their texts, on the grounds that production relationships are the foundation of all human relationships according to Marxist tenets. Kurahara admonished writers who did not have firsthand experience to first learn about working life conditions before sitting down to write (Kurahara, I93 Ib, pp. 59-60). ${ }^{6}$ Kurahara undoubtedly has a point here. The in medias res where one typical strand of Japanese proletarian piece of fiction begins is at a point in time when the workers have laid down their work and the labor dispute is already unfolding, as exemplified here by the opening of Toda Toyoko's (I904-I956) short story "Iron foundry" [Imono kōjō] (I930):

Metal scrap chewed by the cutter, hammers tossed away, shovels stuck in coal heaps, lathes, moulds, chains, other raw material and machines - every position and pose tell vividly of the moment one week ago when negotiations broke down while work was in operation and when decisive action to withdraw all workers was taken. (Toda, I930, p. I02) 
The type of depiction that Kurahara envisaged to be emblematic of proletarian realism was vested in daily working life and could be characterized as a form of reportage literature: "At this moment in time our country's proletarian writers and artists must immerse themselves in every nook and corner of contemporary life and take correct objective and concrete notes of that life" (I928, p. I2). While the leadership sought high and low for literary talent, especially among factory workers in key industries, they came up with little in the end (cf. Clark, 20I7, p. 2). But there were exceptions to the reliance on the "intelligentsia" writing on behalf of workers.

Iwatō Yukio (I902-I989) was once one of Literary Front's representative writers, of whom editors had the highest expectations (Uranishi, I974, p. 60). Iwatō is of special significance since he belonged to the minority of uneducated working-class writers that the movement sought to foster. His most important work, the novel Iron [Tetsu]( I 929), epitomizes common stylistic and thematic features of Japanese proletarian literature as promoted by Kurahara and others. Surveying the literary output of I929, Kurahara even singled it out as a "signpost" of proletarian literature, together with The Crab Cannery Ship (discussed below). In his estimate Iron is the first Japanese proletarian work to portray "living" [ikita] factory workers (Kurahara, I968, p. IO). ${ }^{7}$

The novel's narrative revolves around the I-protagonist Makishima, who has temporarily left Tokyo to return to his provincial hometown after a twenty-year long absence. Here, he divides his time between union activism at the local ironworks where he has taken up employment, and an increasingly chaotic family situation where his grandmother, a devoted Buddhist believer, is caring for his bedridden alcoholic father. The forming of the proletarian Worker Farmer Party [Rōdō nōmin-tō] in 1926 constitutes the historical context against which the fictional events unfold. The appearance on the political scene of this new radical alternative has occasioned the factory's labor union to endeavor to expand the hitherto economic struggle into an outright political one. The workers have been working fourteen hours a day without rest for a month to deliver an order to the Railway Ministry. Juxtaposed with the male ironworks is the 
female arena of the spinning mill situated across the river, a site to where the union is striving to expand. In the opening of the novel, Makishima learns that the marriage of his older sister is breaking up and that she is returning home with her three-year old child. Her husband, a foreman at the mill, is divorcing her ostensibly for having continued a letter correspondence with her former lover, although the protagonist learns that the real reason was his own union activism. Now the remittance from the in-laws will cease, adding to the housekeeping burden of the family.

In the highly contested ideological field of Japan's I920s, one of the main rivalries was played out between Anarcho-syndicalists and Bolsheviks (the debate was known as the Ana-Boru ronsō). In the novel, Iwatō, who himself arrived to Marxism via anarchism, situates this rivalry within the Makishima family by bringing the protagonist's delinquent, anarchist younger half-sister on to the stage. The protagonist remains in his hometown longer than planned because of his feeling of duty to guide his sister onto the correct Marxist path. The novel features a few scenes of heated debate between the two siblings where they throw invectives at each other that replicate commonly held opinions about the other side's cause, as for example in the following:

Sister: 'Cowards! You guys haven't ventured one step out of humanism! I despise you all!'

Brother: 'Is that all the lot of you have to say to us? Is it okay for a person to be satisfied with just conceptual thinking? Are you satisfied to shut yourself up in your tiny, insignificant subjectivity?'

Sister: 'Communism only works in theory, there are no people without egoism. Do you deny human egoism?'

Brother: 'People have emotions of various kinds, but if you bring individualism into the movement it's the end of the story. We have graduated from that kind of emotion long ago.'

Sister: 'Big talk. Why don't you just go on living like you want.' Brother: 'That's what we are fighting for!' (Iwatō, I929, p. I27)

An accident at the factory provides the opportunity for the union to escalate activities. One of the boilers explodes after a manager blocks its safety valve in order to increase the output, killing two workers and one young apprentice working under illegal 
conditions without a contract. When the management contrives a means of blaming the accident on one of the union members, the union responds with a work slowdown. The petition with the workers' demands and the text of the handbills distributed by the union in the factory are supplied in the text, in a similar way to many other proletarian works. ${ }^{8}$ The management responds by firing the union organizers and locking them out from the factory gate. In the end nothing is resolved as the union is defeated by the factory management in collusion with the police. How capitalists operate with different state organs is another favorite topic of Japanese proletarian literature.

When his elder sister drowns herself in the river, Makishima's grandmother blames him for having sacrificed his family in favor of the union. Meanwhile, his younger sister remains adamant in her anti-Communism. She accuses her brother and his comrades of being mere puppets and urges them to blow up the factory in a suicide attack in order to achieve some sort of tangible result. In an interior monologue Makishima admits to being tempted by his sister's words:

Blowing up... an all-out fight that makes you forget yourself, like dying in a drunken stupor. A nihilistic illusion - I couldn't say that I was totally free from that yearning. Deep inside I felt the bitter temptation flash by [...] The union, the Party... I had to stay alive to carry out all the work that needed to be done. Soon a time will come when a mass of tens of millions of hearts moulded in fury will rise up. Then I will die, if my body is called upon. I take pride in being a puppet of my Party and union. (Iwatō, I929, p. I72)

Yet the narrative ends in a cheerful spirit as the union regroups for the next stage of the strife. The battle has been lost but the activists are still fighting the war.

Iwato Yukio was, however, a rather exceptional character in the movement's line-up of writers. In a roundtable discussion in I97 I among veteran activists of the Kanagawa branch of the Writers' League (situated close to Tokyo), it emerged that they had held unfulfilled hopes of at least producing one prominent writer in the area, around whom local activities could be centred. There was a consensus among the discussants that writers simply did not emerge from the factory literary circles that were organized; 
that while workers did have interesting stories to tell, when asked to put them on paper, these stories came out flat and dull. Another significant point that emerged in the roundtable was the high risk involved in joining a circle. Even unaware factory girls with no "red" track record whatsoever were promptly fired for simply having approached a literary circle (Kodera, I97 I, p. 95-98). Not surprisingly, scabs and factory spies are stock characters in many of the works produced, reflecting the extreme measures that were increasingly implemented throughout society against any red tendencies. Interestingly, it is a forgone conclusion in the above discussion that it was more rewarding to read the lenient Literary Front than the more doctrinaire Battle Flag, even though the latter wielded more political clout.

In the end the movement's quest of nurturing writers of a workingclass background remained an unsolved issue. The kinds of novels that were promoted as examples for proletarian writers to emulate were, for example, Alexander Fadeyev's The Rout [Razgrom] (I927), which Kurahara lauded for its depiction of the characters' social and class appearances and their roles in history (Kurahara, I966, p. 296), and especially Fedor Gladkov's Cement [Tsement] ( 1925 ), one of the two main and most popular exemplars of Soviet socialist realism (cf. Clark, 20I7, p. II). In retrospect, it appears somewhat optimisic that uneducated workers would be able to first digest Marxist concepts (for a time writers were admonished to adhere to the method of dialectical materialism) and then integrate them organically into literary pieces. Furthermore, writing against the system, the Japanese writers had no positive historical moment, as they saw it, or ongoing socialist experiment to work with, as their Soviet counterparts had. Still, given that most writers were confined to working under great duress, it is perhaps even surprising that so much of good literary writing was produced. If we boil down the common points of critique leveled against the works produced, we might perhaps conclude that many writers were more adept at telling than showing, to borrow a famous dichotomy. Yet, although the plots might at times appear crude and tendentious - and therefore begging for a different readerly stance to that of belles lettres in general- we must not forget that the works discussed here belong to a genre of literature with a specific purpose. 


\section{Female Writers}

The Proletarian Cultural Movement was undeniably a heavily male oriented endeavor, to the extent of even spawning a contemporary debate about exploited female cultural workers providing sexual favors to their male counterparts. With an anachronistic Japanese term, then, female activists were to some extent treated as comfort women [ianfu] by their male comrades. However, spurred on by international communism's focus on female emancipation in general and on the Japanese women issue directed from Moscow in particular, its leadership strove aggressively to mobilize and involve female intellectuals as well as cultural workers in the movement. One frequently quoted international document in various Japanese leftist publications was the resolutions of the Fifth Congress of the Profintern [Red International of Labour Unions] held in Moscow in August I930. In a chapter of the resolutions specifically devoted to the Japanese case, "Tasks of the Revolutionary Trade Union Movement in Japan," we find the women issue highlighted:

Particular attention must be given by the revolutionary T.U. [trade union] movement of Japan to the organising of the women and the young workers, whose exploitation in the mills and the factories of the country has attained appalling dimensions. The percentage of women in Japanese industry is higher than anywhere else, and any refusal to organize women is tantamount in the Japanese circumstances to serving the bourgeoisie. (Red International of Labour Unions, I93 I, p. I47)

It appears Japan attracted special attention from the international communist movement due to the high rate of inclusion of women in the industrial workforce. In a discussion of the women's journal Women's Arts [Nyonin geijutsu] published from I928 to I932, the literary historian Ogata Akiko has commented on the promise that the Soviet social experiment held forth to some women in Japan. She argues that the left turn that the journal took- by early I930 anarchists writing for the journal had been ousted by more doctrinaire Marxists and the radicalization from here on became conspicuous including introductions to facets of Soviet life- had its own logical causes and was not a mere result of intellectual trends: 
Women who were not allowed to breathe freely anywhere other than within the household - no matter how dark and oppressing the household was and regardless of the fact that in the final analysis not even that household could become a refuge - unhesitatingly chose revolution, Marxism, and the road to Soviet Russia. For Women's Arts, which aspired to women's solidarity and independence, leftist radicalization was brought about by inevitable intrinsic demands that went beyond riding the waves of the times or being swept away by them. (Ogata, I993 [I980], p. 96)

One such female writer who chose revolution was Hirabayashi Eiko (I902-200I). A Writers' League member, Hirabayashi is representative of a type of socially conscientious individual without an academic background whom the movement attracted. Born in the Nagano prefecture, Hirabayashi had to abandon hopes of continuing her education at a girls' higher school when her family was financially ruined. She set out for Osaka alone at the age of sixteen in search of work and education. Eventually, Hirabayashi joined the Writers' League operating in Tokyo after job hopping and a sojourn at the writer Mushanokōji Saneatsu's (I885-I976) utopian project the New Village [Atarashiki mura] in Kyushu. After the Great Kantō Earthquake in 1923, Hirabayashi returned temporarily to Nagano where she worked as the only female newspaper reporter in the whole prefecture. This is how she remembers her own original attraction to the proletarian cause:

I didn't understand much of the theoretical stuff, but at the time I felt a kind of empathy towards the proletarian movement. For a while I wrote only that type of work. I wanted to turn the daily life and sentiment of the proletariat into novels. In the vein of Chekhov, you see. The times being what they were, I thought earnestly of the coming of a world easier for women, workers and other members of the lower classes to live in. Therefore, I wanted to express that wish in the form of literature. The contradictions of the world were just too great, you see. A society where women could live more on their own was absolutely necessary. I was young and, if nothing else, I was full of that sense of justice. (Quoted in Okada, 200I, pp. I49-I 50)

In Hirabayashi's oeuvre, female enlightenment and emancipation become leitmotifs. In her short story “The Origin” (Hottan, I93 I) 
she locates the setting in the proletarian heartland of the factory. Tetsuko, the heroine, belongs to the irregularly employed and poorly paid underclass female clerk squad in the accounts department. She gradually resolves to take a political stance against the company's discriminatory employment policies. Tetsuko had left the countryside with the aim of taking the primary school teachers' examination, mirroring the author's own experiences, but finds merely staying alive day by day in the city a more urgent task: "Armed like a tank, reality crushed her dreams" (Hirabayashi, I93 Ia, p. I I4). The gist of the storyline is Tetsuko's growing impatience with her fellow clerks' lethargy in face of the excess rationalization expected to come in the wake of the Depression. In contrast to the inactivity displayed by this ambivalent social class, the defiance stirring among the company's workers fills her with inspiration. The unrest that has erupted over the injury of a fellow worker is escalating and at the end of the story Tetsuko joins their demonstration:

The misfortune of one human being thus mobilizes five hundred mates. It is a heroic march of a class that has awakened to its own power. It is the appearance of the pent-up rage of workers too long suppressed by unjust authority suddenly coming to a boil. The powerful passion for the future that pierced straight through their core moved Tetsuko violently. (Hirabayashi, I93 Ia, p. I23)

In "Model Factory" [Mohan kōjō] (I93I), situated in the weaving mills - a favorite location for proletarian works detailing the hardships of female workers- of Kyoto's Nishijin district, Hirabayashi yet again treats the deteriorating working conditions and shrinking wages, facilitated by increasing unemployment after the closing down of smaller mills. The story begins in medias res when the weavers rush to the bath after a hard day's work. The text grants access to exclusively female territory rarely encountered in male dominated proletarian literature, particularly in the opening bathhouse scene:

The pushing and shoving of naked bodies trembling with cold had begun in front of the mirror hung on the bathroom wall. The girls' bodies, tortured by excessive labour, a simple diet, and unnatural working postures during the precious growth period, were all of 
an asymmetric, ugly shape. In proportion with the torsos, the legs were thick and short. (Hirabayashi, I93 Ib, p. I09)

The owner has proclaimed his factory a model factory and inspection groups come through endlessly. None of the observers, however, are interested in the weavers or their working conditions, except for one Tokyo city council member who utters his surprise at finding so few Kyoto beauties among the women, while recalling the soft skin of the geisha in the district of Gion where he is staying. To this the narrator impatiently comments that visitors seemingly did not even understand the simple fact that most of the factory girls were not locals, but poor migrant farm girls from the provinces.

In "Model Factory" the second-floor dormitory above the factory constitutes an exclusive female space where female homosocial bonding takes place. The character Omitsu plays the role of leader with the power to arouse enthusiasm in her fellow workers. Despite her powers though, she fails to muster in them enough courage to confront the factory owner with their demands, including the removal of the exhausting weekly Friday night characterbuilding lecture delivered by a Buddhist priest from a nearby temple. Focusing on concepts such as duty and spirit of selfsacrifice, the priest praises a slavish morality that supports loyal service to the employer.

The instigator of change turns out to be a man, Shin-san, who is in charge of heating the bath. Omitsu and her companion Suzue first call on him to ask him to use more coal to keep the fire burning longer. The two of them keep visiting him and under his guidance they start to see things differently. Shin-san criticizes Suzue's religious beliefs and gradually the way she sees the world is turned upside down as a working-class pride begins to germinate. Although Omitsu possesses an intense craving for knowledge, her understanding has so far been disjointed. Shin-san's instruction, however, lends focus and direction to it. Back at the dormitory, the two girls spread the newly gained knowledge among their fellow workers. This enables the women to make sense of their daily discontent. The realization of the need for unity and solidarity starts forming among them. 
Shin-san indicates that a golden opportunity to create the planned labor union has arisen as the branch manager of a bank, which is lending money to the company, is planning an inspection visit. On the morning of the visit, the women lay down their work in unison and present the owner with a petition. With his back to the wall, the owner is left with no other choice than to accept all the demands: to allow no layoffs due to production cuts; to furnish the dormitory with a charcoal brazier; to keep the coal burning throughout the bathing time; to disallow inspection groups to cause unreasonable trouble to the factory girls; to abolish the character-building lecture; and to allow union affiliation. The short story ends on an optimistic note: "Since that day Shinsan disappeared from sight. But he is sure to always return on important occasions. And the seeds that were sown will undoubtedly keep growing" (Hirabayashi, I93 Ib, p. I I9). As the reader has suspected, it turns out that Shin-san had been an agitator- a stock character of proletarian fiction- assigned to the factory by the illegal revolutionary labor union movement to funnel discontent into acts of disobedience. In general, Hirabayashi's prose has a fresh appeal with its swift, graphic portrayal that appears directly influenced by filmic representation, the most fashionable medium at the time. As such, her oeuvre contravenes the reputation of Japanese proletarian literature as trite and stereotypical. The degenerate variant invariably hammers in political dogma in a much more unsophisticated way. ${ }^{9}$

One of Hirabayashi's female colleagues in the Writers' League was the writer activist Matsuda Tokiko (I905-2004). In her "Another Battlefront" ["Aru sensen"] (I932), we get another powerful first-hand report delivered directly from the factory floor. The story is set in the vulcanization division, among the suffocating chemical gas fumes, in a factory redirected to produce war material, a consequence of Japan's increased expansionism following the invasion of Manchuria. As pointed out by Norma Field in the preface to her translation of the short story: "The conditions of work, however, exploitative to begin with, were exacerbated by constant speedups, which in turn intensified the impact of environmental hazards. Given these circumstances, the challenge for the proletarian movement was to secure workers' 
rights and oppose imperialist war" (Bowen-Struyk and Field (eds.), 2016, p. 266). This challenge is an often-featured motif in the sense that many Japanese proletarian works detail the worsening economic conditions on the home front, along with the ramifications of expansionism on the Asian continent.

The story opens on a day when flyers have been distributed, the words of which are sampled through the stream of consciousness of Sadayo, the protagonist: "Now that we're at war, orders come pouring into your factory. You're told to work overtime, to be more efficient as you work with poison gas, but you're not provided with any of the gas masks you yourselves produce" (BowenStruyk and Field (eds.), 2016, p. 268). The plot revolves around the factory management's scheme to break the workers' solidarity by having scabs plant the initiative of "voluntary" donations to the Friendship Association; deductions from salaries would be sent to soldiers in Manchuria and Mongolia. Union organizers, however, outsmart the management through collecting donations for a different purpose: for the support of two dismissed workers in dire straits. In the denouement, the reader is swept along by the surge of workers toward the accounting section on payday. In the bustling throng we are permitted to listen in on the multiple voices of the workers even as we, as readers, are about to lose our foothold while being buffeted around by them. Here, also, the prose is rendered in a filmic mode that gives a strong impression of here and now.

\section{Relevance of Working-Class Literature in Today's Japan}

Publications associated with the Proletarian Cultural Movement peaked at a joint monthly circulation of $\mathrm{I} 60,000$, while around over a thousand cultural circles in all parts of Japan were achieved for a time, indicating the potential for a drastic expansion of activities (Mizuno, I968, p. 543; Ikeda, I97I, pp. 45-46). In the face of an increasingly severe crackdown on leftist activity and police roundups of Communist Party members and cultural workers, however, in 1934 the Writers' League announced its own dismantlement. Undoubtedly, the movement was crushed by reactionary authorities, busy with fostering universal support for 
imperial expansionism on the continent in the citizenry, and who, therefore, decided that they could no longer afford dissent on the home front. Retrospectively, though, most literary historians tend to agree that the movement would have self-imploded anyway, due to internal shortcomings and constant in-fighting. As I have argued elsewhere (20II, p. 58), the movement sealed its own fate by aligning itself with the official ideology imposed in the Soviet Union and by estranging lenient leftist fellow travelers, whom they actually sought to embrace, depicting them as "social fascists" in line with the policy of Comintern after I928. In this respect, Tatsuo Arima's judgement on the movement's sectarian traits appears appropriate: "Preoccupied with the necessity for theoretical impeccability as a prerequisite for conscious proletarian artists, they steadily isolated themselves from the common strata of Japanese society." Arima asserts, "The Marxist intellectuals were in the difficult predicament of facing a hostile government on the one hand and, on the other, of addressing their ideas to the people, to whom purely Marxist symbols meant little" (Arima, I969, p. I79). In retrospect, therefore, it appears incontrovertible that the movement possessed a far greater emancipatory potential as a grassroots cultural enlightenment movement than as harbingers of a revolution that few wanted in the first place, and authorities would never have let happen.

For a long time, the proletarian works of fiction were left to slumber on the shelves of libraries across Japan, seldomly discussed outside of the university seminar rooms. But then, seemingly out of the blue in 2008, Kobayashi Takiji's (1903-1933) seminal novel The Crab Cannery Ship [Kani kōsen] (I929) suddenly became a bestseller with 500,000 copies sold instead of the usual 5,000 copies per year. It's success has spawned manga versions and a remake of the film version. The boom overlapped in time with the reemergence of widespread poverty in Japan and the emergence of the so-called working poor. This new coinage, which became a buzz word in media for a while, sought to encapsulate a new social phenomenon in the wake of the undermining of labor regulations aimed to protect the rights of employees. The new social class of vulnerable irregular employees on temp contracts [hi-seishain], making up the newly coined precariat on the rise in Japan ever since, obviously found inspiration in this classic novel 
that portrays the struggle of the proletariat, the corresponding social class of its time.

The Crab Cannery Ship, the flagship of proletarian novels in Japan, is a fictionalized account of an actual case of brutal treatment of fishermen and factory workers onboard a floating cannery operating in the Sea of Okhotsk that occurred in I926. Kobayashi had set himself a seven-point agenda concerning the novel's intent, most importantly the portrayal of a group of workers as a collective protagonist and the ruling out of the depiction of individual personality or psychology. The novel aligns itself with the common proletarian theme of gradual coming to awareness of class-consciousness, which relates to another of Kobayashi's points on the agenda, to show how capitalism inexorably causes workers to spontaneously organize:

Fishermen who till now had known only servile submission, quite unexpectedly felt a tremendous force thrusting them forward. At first they were bewildered. Gradually they realized that their own power, whose presence they had not suspected, was manifesting itself [...] Once they understood it, a wonderful spirit of rebellion filled their hearts. The very hardships of the agonizing work that had been wrung from them turned into a splendid foundation for their defiance. Now the manager and his ilk could go to hell! They were elated. This new feeling suddenly enabled them to see their wormlike lives vividly, as though illuminated by a flashlight's beam. (Cipris, 2013, p. 79)

This novel of working-class realism has aged well, making it worthy of a revival. Despite some tendentious commentary on the plot on behalf of the narrator as illustrated in the above quotation and despite the sometimes-implausible story elements, like the overly idyllic portrayal of the Russian family that the shipwrecked fishermen encounter after being washed up on the Kamchatka shore, the main thrust of the novel still holds. It is the powerful and vivid description of life and work onboard the cannery ship that make the novel stand out.

But the novel is not only interesting as a case history of extreme exploitation of the workers onboard the ship. The fisherman and young factory hands are enticed by the opportunity to earn a few yen in the seasonal floating crab industry only to be beaten body 
and soul by the system. They are poor tenant farmers' sons from Hokkaido and the northeast region of Japan, or workers enlisted via a Tokyo agency. In this context the association with today's haken rōdōsha, or dispatched temp workers, making up an increasingly larger proportion of Japan's workforce, spontaneously comes to mind. With Japan opening up its labor market to unskilled foreign migrant workers through new legislation implemented in 2019 to battle a severe labor shortage, one can only surmize that The Crab Cannery Ship will gain a renewed relevance going ahead. Although Kobayashi's and other proletarian writers' brand of unionism relates to a totally different sociopolitical milieu, and although perhaps no one believes in revolution any longer, their ardent appeal to solidarity has still to reach its best before date.

\section{Endnotes}

I. Although not racially different from other Japanese, the burakumin (the official word used to refer to this group is hi-sabetsumin, or "those discriminated against") had been confined to play the role of "Untermensch" through their historical connection with occupations associated with death, like tanners, that were considered impure according to Shinto religion and therefore shunned.

2. The pronoun "him" is used in this case as literature was an overwhelmingly male preoccupation at the time.

3. The activist writer Kobayashi Takiji (I903-I933) who was tortured to death by the police after arrest, for instance, joined the Japanese Communist Party in I93I. For an inside view of activism within the movement, see his Life of a Party Member [Tōseikatsusha] (1932) in Cipris, 20I3, pp. $22 \mathrm{I}-293$.

4. It should be noted that Hayashi is today largely remembered as a turncoat, the first writer to deal the movement a serious blow from an insider position when he announced his defection in 1932, on the ground, as he put it, that he had been torn between the poles of politics and literature: he had come to realize that he had been deprecating literature in the name of politics while simultaneously belittling himself as a writer (cf. Hayashi, I932).

5. These journals were intended as the most easily accessable, popular outlets within the movement. While focusing on creative writing, 
both of them carried all kinds of leftist discourse, although especially the doctrinaire faction of the movement also published specialized journals devoted to more theoretical explication.

6. Here Kurahara writes under the penname Tanimoto Kiyoshi.

7. Kurahara is obviously referencing contemporary Soviet discourse here. Cf. 'The efforts to carry out the cultural plans designed to alter the face of the country were to be directed toward molding the public mind and shaping a perfect socialist man with appropriate psychology, emotions, and behavior. It was only logical that proletarian literature should serve as an agent of the cultural revolution. It was to carry out its mission by engaging in a "deepened psychological analysis" of fictional characters and in presenting them as real "living people," complex and contradictory individuals. These propositions were incorporated in the collective programmatic declarations of the VAPP (later RAPP) [the dominant proletarian literary grouping, which turned into a mass movement with branches and affiliated organizations throughout the Soviet Union] leadership, which served as literary dictates and provided a foundation for further theoretical work (Ermolaev, I963, p. 61).

8. Many Japanese proletarian works of fiction actually read like do-it-yourself manuals of labor conflicts, often with petitions to the enterprise management and handbills to be smuggled in to the factory floor highlighted graphically on the page, framed against the body of the text, almost as if to facilitate cutting them out for actual use. A typical novel that does this is Kaji Wataru's (I903-I982) serialized novel Mobilization Line [Dōin-sen] (I929-1930). See, for instance: Kaji, I929, pp. 62-63.

9. For contemporary commentary on this matter, see for instance: Hirabayashi Taiko, "On the Tendency of Proletarian Works to Become Formulaic," in Bowen-Struyk and Field (eds.), 20I6, pp. I80-183; Kurahara, I93 I, p. I7). For an unfavorable overview of Japanese proletarian literature that reiterates common points of criticism against the genre, see Keene, I998, pp. 594-628.

\section{References}

Arima, T. (1969). The Failure of Freedom. A Portrait of Modern Japanese Intellectuals. Cambridge, Mass, Harvard University Press. 
Beckman, G. \& Okubo, G. (I969). The Japanese Communist Party, I922-I945. Stanford, Stanford University Press.

Bowen-Struyk, H. \& Field, N. eds. (2016). For Dignity, Justice, and Revolution. An Anthology of Japanese Proletarian Literature. Chicago, University of Chicago Press.

Cipris, Z. trans. (2013). The Crab Cannery Ship and Other Novels of Struggle. Honolulu, University of Hawai'i Press.

Clark, K. (20I7). "Working-Class Literature and/or Proletarian Literature. Polemics of the Russian and Soviet Literary Left." In J. Lennon and M Nilsson, eds. Working-Class Literature(s). Historical and International Perspectives. Stockholm, Stockholm University Press. DOI: https://doi.org/IO.I6993/bam.b

Ermolaev, H. (1963). Soviet Literary Theories 1917-1934. The Genesis of Socialist Realism. Berkeley, University of California Press.

Hayashi, F. (I932). "Sakka toshite.” Shinchō, 29 (9), pp. 57-65.

Hayashi, F. (I955). Bungakuteki kaisō. Tokyo, Shinchōsha.

Hirabayashi, E. (I93 Ia). "Hottan.” Nyonin geijutsu, 4 (2), pp. I I 2-I 23.

Hirabayashi, E. (I93 Ib). "Mohan kōjō.” Nyonin geijutsu, 4 (8), pp. I07-II9.

Ikeda, H. (I97I). Nihon puroretaria bungaku undō no saininshiki, Tokyo, San'ichi Shobō.

Iwatō, Y. (I929). “Tetsu,” Bungei sensen, 6 (3), pp. I IO-I73.

Kaji, W. ( I929). ”Dōin-sen,” Senki, 2 ( ( 2), pp. 50-66.

Karlsson, M. (20I I). "United Front from Below. The Proletarian Cultural Movement's Last Stand, I93I-34." Journal of Japanese Studies, 37 (I), pp. 29-59.

Kawaguchi, H. (I97I). Bungaku undō no naka ni ikite. Chūō Daigaku Shuppanbu.

Keene, D. (1998). Dawn to the West. Japanese Literature of the Modern Era. New York, Columbia University Press.

Kodera, A. et al. (I97I). "Keihin sengo bungaku undōshi: senzenhen." Keihin bungaku, inaugural issue, pp. 87-IоI. 
Kurahara, K. (I928). "Seikatsu soshiki toshite no geijutsu to musan kaikyū.” Zen’ei, I (4), pp. 7-I 2.

Kurahara, K. (I93Ia). "Geijutsuteki hōhō ni tsuite no kansō (zenpen).” Nappu, 2 (9), pp. I 2-35.

Kurahara, K. ( I93 I b). “Geijutsuteki hōhō ni tsuite no kansō (kōhen).” Nappu, 2 (Iо), pp. 52-77.

Kurahara, K. (I966). "Futatabi puroretaria rearizumu ni tsuite." Kurahara Korehito hyōronshū, Vol. I. Tokyo, Shin Nihon Shuppansha, pp. 290-299.

Kurahara, K. (I968). “I929-nen no Nihonbungaku.” Kurahara Korehito byōronshū, Vol. 2. Tokyo, Shin Nihon Shuppansha, pp. 3-I 2.

Mizuno, A. (I968). "Kaisetsu.” Kurahara Korehito hyōronshū, Vol. 2. Tokyo, Shin Nihon Shuppansha, pp. 525-552.

Ogata, A. (I993). ”Nyonin geijutsu” no sekai. Hasegawa Shigure to sono shühen. Tokyo, Domesu Shuppan.

Okada, T. (200I). Kaze ni mukatta onnatachi. Tokyo, Chūsekisha.

Red International of Labour Unions. (I93 I). Resolutions of the Fifth Congress of the R.I.L.U. London, The Minority Movement.

Toda, T. (I930). “Imono kōjō.” Nyonin geijutsu, 3 (I I ), pp. IO I-I I 3.

Uranishi, K. (I974). "Iwatō Yukio no 'Tetsu' to 'Chingin dorei sengen'.” Kokubungaku, 50, Kansai Daigaku Kokubungakkai, pp. 59-74. 